\title{
The Cultural Value of Gorontalo as the Basis of Reconstruction of the Model of Organization and Finance Management of the Karawo Artisans in Indonesia
}

\author{
Niswatin \\ State University of Gorontalo \\ niswatin.imran@yahoo.com
}

\author{
Hanisah Hanafi \\ State University of Gorontalo \\ hanisahhanafi65@gmail.com
}

\author{
Rahayu Indriasari \\ State Tadulako of University \\ indriasari398@gmail.
}

\begin{abstract}
Karawo is an art work in the form of an embroidery possessing a high art and economic values. This is among the featured products of Gorontalo, Indonesia. Artisans play a major role in the development of this art industry. Limited economic resources force the artisans to cooperate with other parties in which puts the artisans a disadvantage; this is due to the poor management of the organization and the finance. This research aims to identify the cultural values of Gorontalo which serve as the grounding in designing a model of the management of the organization and finance of the artisans. This qualitative research employed two data collection methods, i.e., observation and Focus Group Discussion, or FGD in short. Validating the data was through a rigorous observation during an interview. Moreover, the steps, such as data reduction, data display, and summing up the analysis, were applied to explore the issue. The results showed three cultural values of Gorontalo, i.e., huyula (community works), dulohupa (discussion), and mo'odelo (responsibility or honesty) serving as the grounding in designing a model of the management of the organization and finance of the Karawo artisans. These values were also categorized as the exclusive local culture to the people of Gorontalo.
\end{abstract}

Keywords: Karawo, Gorontalo culture, organization and finance management of the artisan

\section{INTRODUCTION}

The study of sociology in the field of management and accounting can lead sciences to the social and cultural realities as well as social norms that animate the lives of individuals and societies [1], [2], [3]. This study of sociology considers that individuals and their communities have their own uniqueness in their social life. Contextually, accounting is the part of dynamic social science, along with the dynamic development of societies.

The study of accounting sociology in the perspective of gender has been a concern to researchers [4]. Accounting as a social science views that feminism (women) has an emancipatory role that is able to adjust their work to a balance in family life, and their behavior can determine social and cultural norms of societies [5].

One of the cultural capitals of Gorontalo people in Indonesia that is from the female interaction is Karawo [6]. Karawo is an ornament (craft) of fabric embroidery made of a high difficulty level that begins from the process of cutting and pulling out the yarns, and then embroidering and making a Karawo-patterned design by using different yarns to create a background motive [7]. As a cultural product, the existence of Karawo is currently experiencing a value shift from artwork to a product with high economic value. Therefore, Karawo is one of the developed cultures in supporting creative industry in Gorontalo [8], [9].

The local government and Bank Indonesia organize Karawo festival annually in order to preserve and develop Karawo. As a brand image of Gorontalo people, Karawo has experienced the expansion of domestic and international market access, and has given a positive impact on the economy, on artisans in particular [10][12]. Due to its high economic value, Karawo has been a main business and alternative business for the artisans who dominantly are Gorontalo women. The preservation and development of Karawo are greatly determined by artisans as human capital [13], [14]. Based on the data from Office of Industry, Trade, Cooperatives \& Micro, Small and Medium Enterprises of Gorontalo Province, there are more than 4.541 artisans in this province.

Karawo has undergone social construction changes from symbols with cultural value to symbols with an economic value. Karawo existence has met a period of industrialization in order to support creative industry [15]. Regarding this, it presents new organizational and financial management models for artisans with economic motives, including: in the form of centers, cooperatives, patronage systems, and single systems [16].

From the aspect of socio-culture, Gorontalo does not only have a cultural product of Karawo that should be preserved, but also have cultural values or a distinctive value system that can be integrated into the aspects of people's lives, including in the organizational and financial management aspects of Karawo artisans. This study aims to explore Gorontalo culture and its values as the basis of reconstructing organizational and financial management of Karawo artisans. The output of this study 
can serve as a basis for further researchers to discover the meaning of value and its implementation in revitalizing institutional model so that Gorontalo cultural valuesbased organization will be created.

\section{METHOD}

This study used a qualitative approach in which the researchers were the primary instruments in collecting and analyzing the data. In this approach, the researchers made a complex description of the situation, examined the words and detailed reports from the informants' point of view as well as observed the natural situation. Ethical perspective was selected because the research results were categorized by referring to the concepts from the research data.

This study involved Karawo artisans and partners as the subjects, either the societies or institutions that interact with artisans in Gorontalo Regency and surrounding areas. The object of research was the culture and its values practiced by the artisans of Karawo and their partners. The primary data were from the interview results through Focus Group Discussion (FGD) with Karawo artisans and interviewees involved as artisan partners, such as financiers and traders, along with the experts involved in to guide the artisans, who were academics/researchers in universities, sociologists, humanist, the head of industry, trader, cooperatives \& micro, small, and medium enterprises office, and the head of Bank Indonesia of Gorontalo. The secondary data, on the other hand, were from the observation results of artisans' activities in the field and other documentations.

The data validity test was carried out by conducting source triangulation by comparing the observation results of artisans' activities to the interview results, comparing the interview results of the artisans to the experts through FGD, and extending the time of observation by joining Karawo festival activities undertaken by the local government in cooperation with Bank Indonesia of Gorontalo. The data were analyzed through three steps: 1) data reduction; classifying and eliminating unnecessary data, 2) data presentation; understanding what happened and what was done to have a comprehension gained from data presentation, and 3) drawing conclusion; creating a concept of culture and its values as a result of research findings.

\section{RESULT}

This study figured out three cultures (cultural system) of Gorontalo and its values as the local culture of Gorontalo people found in Karawo artisans' reality to communicate with the artisans, business partners, and other communities involved in the development of Karawo. They are presented in Table 1.
Table 1. The three cultures of Gorontalo

\begin{tabular}{|c|c|}
\hline Culture & Values \\
\hline Huyula & $\begin{array}{c}\text { Cooperation, } \\
\text { togetherness, mutual } \\
\text { assistance, empathy, } \\
\text { and care. }\end{array}$ \\
\hline Dulohupa & $\begin{array}{c}\text { Discussion/agree } \\
\text { ment }\end{array}$ \\
\hline Mo'odelo & $\begin{array}{c}\text { Being } \\
\text { responsible, } \\
\text { trustworthy, and } \\
\text { innovative }\end{array}$ \\
\hline
\end{tabular}

Firstly, the culture of huyula is reflected by the values of cooperation, togetherness, mutual assistance, empathy, and care. The reflection of these values appears in the form of interaction among the artisans in the process of making Karawo. Karawo received recognition from the Ministry of Law and Human Rights of Indonesia as a patent of Gorontalo with Patent ID 0012784 and Patent Application Number P-00200500324 (Change S00200400151). Karawo as an artwork of embroidery belongs to craft that has a level of difficulty and uniqueness in the making process as well as has differences from other types of embroidery in Indonesia. Accordingly, Karawo won an award as the most unique embroidered craft around the archipelago in Festival Sulaman Nusantara (Archipelago Embroidery Festival) at Museum Gajah, Jakarta [17].

The process of making Karawo is performed through four steps: 1) creating motives functioning as the pattern in the process of cutting and pulling out the yarns on the fabric, 2) cutting and pulling out the yarns, 3) embroidering, 4) finishing/making a Karawo-motive design. In fact, there is no artisan who has all skills in the process of making Karawo. Generally, each of them only has one skill in the making process. To complete one Karawo embroidery on a piece of fabric, it needs four artisans who have different roles. For that reason, the values of cooperation, togetherness, mutual assistance, empathy, and care among the artisans are required in order to create Karawo.

Secondly, the culture of dulohupa is reflected by the value of discussion/agreement. The reflection of this value emerges in the form of interaction among the artisans and the partners (financiers, traders, and consumers). It revealed that the artisans do not directly get in touch with the consumers or traders of embroidery fabric. The artisans are coordinated in a group consisting of at least four artisans and one as the group leader to mediate the artisans with the consumers or embroidery fabric traders. The group leader, sometimes, plays a role as the financier who provides the raw material needs, and determines the fee given to the artisans.

The problem that sometimes occurs between the artisans and the group leader is related to the distribution of orders and the determination of fee for the artisans. In consequence, a discussion/agreement has become the value that must be agreed so that there is a harmonious 
relationship between artisans and the group leader. This harmonious relationship will affect the team continuity that has been formed.

Thirdly, the culture of mo'odelo is reflected by the values of being responsible, trustworthy, and innovative. The reflection of these values appears in form of interaction among the artisans, partners, and other stakeholders. Karawo artisans have a principle that finishing the embroidery orders is a form of responsibility to God as the Creator and gratitude to Him who has given work or income to them. In addition, responsibility is also addressed to the group leader and consumers. This responsibility is seen by the effort to finish the embroidery neatly, beautifully, and punctually. The artisans admit that the admiration of Karawo consumers depends on their hands.

The artisans realize that Karawo has become a credited cultural product of Gorontalo people that should be preserved and developed. The artisans have been trusted from local government and other stakeholders as the parties that determine the preservation and development of Karawo. On that ground, the artisans always strive to improve the quality of embroidery by making innovations in the design and embroidery products in accordance with the consumers' needs. They are even very active in supporting the activities of local government, other institutions, and universities (stakeholders) to preserve and develop Karawo, including joining the coaching program and annual Karawo festival.

The industrialization of Karawo has brought a livelihood shift effect for artisans from alternative business to main business. The main problem faced by the artisans is the lack of skill in financial management, especially providing capital. Hence, innovation of basic knowledge of management accounting as a foundation of knowledge in financial management is indispensable for business progress [18].

These three cultures and values are the social capital owned by Gorontalo people, particularly the artisans of Karawo [19]. Those culture and values are in line with the life philosophy of most people in Gorontalo who are Muslim, namely adat bersendikan syarak, syarak bersendikan kitabullah which means 'Tradition is rooted in Sharia, Sharia is rooted in the Quran' [20]. Karawo is not only acknowledged as a cultural product, but also a distinctive cultural system implemented in the making, preservation, and development process.

If these values are integrated into the organizational and the financial management models of the artisans, there will be an organization that is not only oriented to the economic needs, but also to social and spiritual life. Therefore, the culture and its values show the harmonious relationship of the artisans with God as the Creator, humans, nature and the environment. The social capital of an organization contributes to the improvement of the organizational innovation potency, and ultimately can maintain the existence of an organization [21]. To support revitalizing efforts of the organizational and financial management of artisans which are not only economic-oriented, stakeholders as the policy maker should contribute to make various rules to accommodate all aspirations of organizational problems of Karawo artisans [14].

\section{CONCLUSION}

Based on the description of research results, this research found three of Gorontalo cultural values which can be used as the basis in designing organizational and financial management models of Karawo artisans. They are huyula (mutual assistance), dulohupa (discussion / agreement), and mo'odelo (responsibility / trust). The three cultures have values that are in line with Islamic values, as the life philosophy embraced by the people of Gorontalo, namely adat bersendikan syarak, syarak bersendikan kitabullah 'Tradition is rooted in Sharia, Sharia is rooted in the Quran'.

The importance of this study is to strengthen Gorontalo culture, both the work of culture/physical culture (Karawo) and the implementation/integration of cultural values/cultural system (local culture) of Gorontalo into organizational and financial management models that are intended to improve the productivity and welfare of Karawo artisans to support the creative industry. The contribution of this study is the integration of cultural values (local culture) of Gorontalo into an organizational and financial management model of Karawo artisans in doing business that will enrich their knowledge. This indicates that value has a position as a guideline in presenting a concept of science.

This research is limited to the exploration of Gorontalo cultural values as the basis for reconstructing the models of organizational and financial management of Karawo artisans. Therefore, in order to be implemented, further research is suggested to figure out the forms of organizational and financial management models of Karawo artisans which are in line with Gorontalo culture and how cultural values are integrated/implemented.

\section{REFERENCES}

[1] F. Management, "Accounting as Social Science : Some Implications for Teaching and Research Tony Lowe and Tony Puxty,” pp. 54-72, 1990.

[2] A. Mennicken, "Bringing Calculation back in: Sociological studies in accounting," Max Planck Inst. study if Soc., vol. Vol. 3, no. Iss 3, pp. 17-27, 2002.

[3] S. J. Ball, "Accounting for a sociological life : influences and experiences on the road from welfarism to neoliberalism," vol. 5692, no. January, 2016

[4] C. Bartholomaeus and A. S. Senkevics, "Accounting for gender in the Sociology of Childhood: Reflections From Research in Australia and Brazil," 2015. 
[5] K. Haynes, "Critical Perspectives on Accounting Accounting as gendering and gendered: A review of 25 years of critical accounting research on gender," Crit. Perspect. Account., 2016.

[6] Hadi, Rahmatiah, Jumadi, and Sulaiman Samad, "The Role of Human Capital in the Development of Sulam Karawo Creative Industry in Gorontalo," Int. J. Acad. Res., vol. Vol. 7, no. No. 1, p. pp 158-162, 2015.

[7] I. W. Sudana, "Characteristics of Karawo The Textile Ornaments From Gorontalo," in Prosiding International Seminar on Conservation of Cultural Heritage, 2015.

[8] R. A. Isa, "Developing Karawo Industrial Center in Increasing Society's Income in Gorontalo Distric of Gorontalo Province, Indonesia," $J$. Econ. Sustain. Dev., vol. Vol. 5, no. No. 23, p. pp 2205-208, 2014.
[9] Bank Indonesia, "Program Pengembangan Klaster Sulaman Karawo Provinsi Gorontalo.” Dokumen Bank Indonesia Perwakilan Indonesia, 2013.

[10] Niswatin, I. Igirisa, H. Hanafi, and M. Ahmad, "Institutional and financial management model of karawo crafters in Gorontalo," Res. J. Financ. Account., vol. Vol. 8, no. No. 20, p. pp, 2017.

[11] O. L. Lopez and M. R. W. Hiebl, "Management Accounting in Small and Medium- Sized Enterprises Current Knowledge and Avenues for Research," J. Manag. Account. Res., vol. Vol. 27, no. No. 1, p. pp 81-119, 2015.

[12] A. S. Niode, Perubahan Nilai-nilai Budaya dan Pranata Sosial. Jakarta: PT. Pustaka Indonesia Press, 2007.

[13] K. Mahmood, "Social Capital: From Concept To Theory," Pak. J. Sci., vol. Vol. 7, no. No. 1, 2015.

[14] O. Elinor, "Crafting Analitical Tools to Study Institutional Change," J. Institutional Econ., vol. Vol. 7, no. No. 3, pp. 317-343, 2011. 